\title{
DNA barcoding of Austrian snow scorpionflies (Mecoptera, Boreidae) reveals potential cryptic diversity in Boreus westwoodi
}

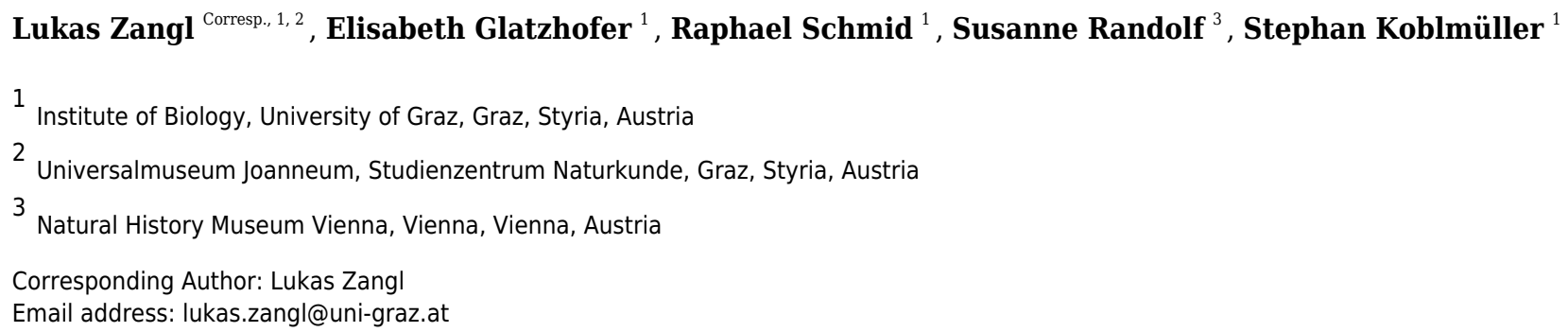

Background. Snow scorpionflies (genus Boreus) belong to a family of Mecoptera, Boreidae, that has been vastly neglected by entomological researchers due to their shift in seasonality to the winter months. Their activity during this time is regarded as a strategy for predator avoidance and regular sightings on snow fields suggest that this also facilitates dispersal. However, many aspects about snow scorpionflies, especially systematics, taxonomy, distribution of species, phylogenetics and phylogeography have remained fairly unexplored until today. In this study, we fill some of these gaps by generating a reference DNA barcode database for Austrian snow scorpionflies in the frame of the Austrian Barcode of Life initiative and by characterising morphological diversity in the study region. Methods. Initial species assignment of all 67 specimens was based on male morphological characters previously reported to differ between Boreus species and, for females, the shape of the ovipositor. DNA barcoding of the mitochondrial cytochrome $c$ oxidase subunit 1 (COI) gene was carried out for all 67 samples and served as a basis for BIN assignment, genetic distance calculations, as well as alternative species delimitation analyses (ABGD, GMYC, bGMYC, bPTP) and a statistical parsimony network to infer phylogenetic relationships among individual samples/sampling sites. Results. Morphological investigations suggested the presence of both Boreus hyemalis and Boreus westwoodi in Austria. DNA barcoding also separated the two species, but resulted in several divergent clades, the paraphyly of $B$. westwoodi in Austria, and high levels of phylogeographic structure on a small geographic scale. Even though the different molecular species delimitation methods disagreed on the exact number of species, they unequivocally suggested the presence of more than the tradiationally recognized two Boreus species in Austria, thus indicating potential cryptic species within the genus Boreus in general and especially in $B$. westwoodi. 
1 DNA barcoding of Austrian snow scorpionflies (Mecoptera,

2 Boreidae) reveals potential cryptic diversity in Boreus

3 westwoodi

4

5

6

7

8 9 10

12

13

14

15

16

17

18

19

20

21

22

23

24

25

26

27

28

29

30

31

32

33

34

35

36

37

38

39

Lukas Zangl ${ }^{1,2}$, Elisabeth Glatzhofer ${ }^{1}$, Raphael Schmid ${ }^{1}$, Susanne Randolf ${ }^{3}$, Stephan Koblmüller ${ }^{1}$

${ }^{1}$ Institute of Biology, University of Graz, Universitätsplatz 2, 8010 Graz, Austria

${ }^{2}$ Universalmuseum Joanneum, Studienzentrum Naturkunde, Weinzöttlstraße 16, 8045 Graz, Austria

${ }^{3}$ Natural History Museum Vienna, Burgring 7, 1010 Vienna, Austria

Corresponding Author:

Lukas Zang $1^{1}$

Universitätsplatz 2, Graz, 8010, Austria

Email address: Lukas.zangl@uni-graz.at

\section{Abstract}

Background. Snow scorpionflies (genus Boreus) belong to a family of Mecoptera, Boreidae, that has been vastly neglected by entomological researchers due to their shift in seasonality to the winter months. Their activity during this time is regarded as a strategy for predator avoidance and regular sightings on snow fields suggest that this also facilitates dispersal. However, many aspects about snow scorpionflies, especially systematics, taxonomy, distribution of species, phylogenetics and phylogeography have remained fairly unexplored until today. In this study, we fill some of these gaps by generating a reference DNA barcode database for Austrian snow scorpionflies in the frame of the Austrian Barcode of Life initiative and by characterising morphological diversity in the study region.

Methods. Initial species assignment of all 67 specimens was based on male morphological characters previously reported to differ between Boreus species and, for females, the shape of the ovipositor. DNA barcoding of the mitochondrial cytochrome c oxidase subunit 1 (COI) gene was carried out for all 67 samples and served as a basis for BIN assignment, genetic distance calculations, as well as alternative species delimitation analyses (ABGD, GMYC, bGMYC, bPTP) and a statistical parsimony network to infer phylogenetic relationships among individual samples/sampling sites.

Results. Morphological investigations suggested the presence of both Boreus hyemalis and Boreus westwoodi in Austria. DNA barcoding also separated the two species, but resulted in several divergent clades, the paraphyly of $B$. westwood $i$ in Austria, and high levels of phylogeographic structure on a small geographic scale. Even though the different molecular species delimitation methods disagreed on the exact number of species, they unequivocally 
40

41

42

43

44

45

46

47

48

49

50

51

52

53

54

55

56

57

58

59

60

61

62

63

64

65

66

67

68

69

70

71

72

73

74

75

76

77

78

79

suggested the presence of more than the tradiationally recognized two Boreus species in Austria, thus indicating potential cryptic species within the genus Boreus in general and especially in $B$. westwoodi.

\section{Introduction}

The holometabolous insect genus Boreus (Mecoptera: Boreidae), commonly known as snow scorpionflies or winter scorpionflies (Ibrahimi et al., 2018), has a Holarctic distribution and is most famous for its cold tolerance and activity on snow (Hågvar \& Østbye, 2011). The imagines occur from about October to March/April (Finch, 1997; Hågvar, 2001), a temporal niche, which, among other hypotheses, has been attributed to predator avoidance and improved dispersal (Hågvar, 2010). Snow scorpionflies predominantly feed on mosses, but are also known to process decaying insects (Finch, 1997). Despite a basic understanding of their general biology (Finch, 1997; Hågvar, 2001; Hågvar, 2010), gaps in the knowledge concerning their distribution and species richness are yet to be overcome (e. g., Willmann, 1978; Hågvar \& Østbye, 2011; Ibrahimi et al., 2018). However, most of the existing literature unanimously reports Boreus hyemalis (Linnaeus, 1767) and Boreus westwoodi Hagen, 1866 from Southwest Europe to Northeast Scandinavia, and consequently also from Austria (Willmann, 1978; Devetak, 1988; Finch, 1997; Raemakers \& Kleukers, 1999, Kreithner, 2001; Hågvar \& Østbye, 2011; Tillier et al., 2011; Ibrahimi et al., 2018). Field studies suggested similar ecological preferences for these two species (Hagvar, 2010 and references therein) and therefore some authors have also regarded them as only one species (e.g. Saure, 2003). Other species like Boreus lokayi Klapálek 1901(Romania, Slovakia), Boreus aktijari Pliginskij, 1914 (Crimea) or Boreus kratochvili Mayer, 1938 (Czech Republic) are only scarcely mentioned in the literature (Penny, 1977; Willmann, 1978; Kreithner, 2001; Ibrahimi et al., 2018) and the latter one is even regarded a synonym of B. hyemalis (Kreithner, 2001). Boreus gigas Brauer, 1876 is another ambiguous taxon, which is currently also considered a synonym of $B$. hyemalis and even lacks a formal species description at all (Willmann, 1978). In the past, descriptions of Boreus species were based exclusively on morphological characters (Brauer, 1876; Mayer, 1938; Blades, 2002). Morphological similarity, plasticity and overlapping ranges, though, have issued continuous discussions about their validity (Willmann, 1978 and references therein; Kreithner, 2001) and consequently the distribution of distinct species across Europe in general (Willmann, 1978; Finch, 1997; Kreithner, 2001), but also for Austria in particular (Gepp, 1982; Kreithner, 2001; Gruppe and Aistleitner, 2011). A detailed morphological study compared material from the Alps (Austria, Switzerland, Slovenia, Italy and France) with specimens from Croatia and Sweden and provided a set of morphological characters for species discrimination, spanning some of the intraspecific and geographic morphological variation (Kreithner, 2001). However, no relevant genetic information of European Boreus species has been available so far.

Since DNA barcoding was introduced as a method for biological species discrimination (Hebert et al., 2003), several studies have shown that its delimiting powers also apply to various insect groups (e.g., Raupach et al., 2016; Huemer et al., 2019; Zangl et al., 2019; Galimberti et al., 
80

81

82

83

84

85

86

87

88

89

90

91

92

93

94

95

96

97

98

99

100

101

102

103

104

105

106

107

108

109

110

111

112

113

114

115

116

117

118

119

2020). However, DNA barcoding also has well known limitations with respect to recently diverged species, large population sizes retaining divergent haplotypes and hybridization/introgression (e.g., van Velzen et al., 2012; Ermakov et al., 2015; Cong et al., 2017; Zangl et al., 2020; Paill et al., 2021), and species delimitation therefore benefits from additional sources of data (e.g., Trewick, 2008; Liu et al., 2017). Conducted in the framework of the Austrian Barcode of Life initiative (ABOL, www.abol.ac.at; Haring et al., 2015), the present study aims at i) contributing DNA barcodes of Austrian Boreus species to the Barcode of Life database (BOLD; www.boldsystems.org; Ratnasingham \& Hebert, 2007), ii) investigating their genetic diversity, iii) validating the two proposed Central European species with genetic data and iv) testing whether genetic results mirror the morphological variability displayed by both $B$. hyemalis and B. westwoodi.

\section{Materials \& Methods}

All specimens investigated in the present study were collected in concordance with state conservation laws and under following permits granted by the Amt der Steiermärkischen Landesregierung, Abt. 13 Umwelt und Raumordnung and the Amt der Kärtner Landesregierung, Abt. 8 Umwelt, Energie und Naturschutz, respectively: ABT13-53S-7/1996-156, ABT13-53W50/2018-2, 08-NATP-845/1-2019(007/2019), N-2018-326688/8-Pin). From 2017 to 2020, 67 individuals from 18 Central and Eastern Austrian localities were caught by hand and stored in 2 $\mathrm{ml}$ Eppendorf tubes in pure Ethanol at $-20^{\circ} \mathrm{C}$ (information on species determinations, collection and storage is available on BOLD (dx.doi.org/10.5883/DS-BOREUS), Table S1). Morphological species discrimination followed Penny (1977) and Kreithner (2001). Primarily, the shape of tergal apophyses (TA), gonostyles (GS), epiandrum (EA) and hypandrum (HA) of males was used to assign specimens to species, as these have been identified as the most reliable discriminating characters in previous studies (Kreithner, 2001 and references therein). Due to the unexpected genetic diversity recovered by the DNA barcoding (see below), further morphological investigation included the properties of the caput, the number of antennal segments and the number of bristles on the front wing. These characters, however, have been regarded as questionable or even unsuited for species discrimination in previous studies (Kreithner, 2001 and references therein) but we wanted to check if they show any correspondence to the genetic results. For females, Kreithner (2001) suggested the shape of the ovipositor and especially of the gonocoxosternites which we also used as the primary distinctive character. A Keyence digital microscope was used to assess TA, EA and HA in males and to capture the general appearance of all specimens.

For DNA analyses, total genomic DNA was extracted from three legs using the NucleoSpin Tissue XS Micro kit (Macherey-Nagel) following the manufacturer's instructions. PCR amplification, purification and chain termination sequencing using the primer set $\mathrm{C}_{-}$LepFolF and C_LepFolR (Hernández-Triana et al., 2014) followed Koblmüller et al. (2011) and Duftner et al. (2005). Sequences were visualized on a 3500xl capillary sequencer (ABI) and aligned by Muscle in MEGA 6.06 (Tamura et al., 2013). Clustering analysis based on a Neighbor-Joining (NJ) tree 
120

121

122

123

124

125

126

127

128

129

130

131

132

133

134

135

136

137

138

139

140

141

142

143

144

145

146

147

148

149

150

151

152

153

154

155

156

157

158

159

was performed using the "Taxon ID Tree" tool implemented on BOLD (www.boldsystems.org) based on a muscle alignment and employing the pairwise deletion option. Genetic distances within and between main lineages/species were calculated using the "Barcode Gap Analysis" tool, also provided on BOLD. Furthermore, we estimated divergence times by translating COI distances under the assumption of a general arthropod divergence rate of 1.5\% (Quek et al. 2004). Sequences of Boreus borealis (KU874461.1, KU874462 (Sikes et al., 2017)), a North American representative of the genus, were downloaded from GenBank and used as outgroup. For molecular species delimitation, BIN assignment on BOLD (Ratnasingham \& Hebert, 2013), the Automatic Barcode Gap Discovery (ABGD) (Puillandre et al., 2011), the Bayesian Poisson Tree Processes (bPTP) model (Zhang et al., 2013), the Generalized Mixed Yule Coalescent (GMYC) (Zhang et al., 2013, and the Bayesian GMYC (bGMYC) (Reid \& Carstens, 2012) were used. ABGD was performed via the web version

(https://bioinfo.mnhn.fr/abi/public/abgd/abgdweb.html) using default settings and each of the three distance models Kimura (K80) TS/TV, Jukes-Cantor (JC69) and Simple Distance (results are reported for the Kimura (K80) TS/TV model here as they did not vary between the different models). As input tree for the bPTP analysis, a Maximum Likelihood (ML) tree was inferred via the web-version of PhyML 3.0 (http://www.atgc-montpellier.fr/phyml/; Guindon et al., 2010), employing the HKY model (selected by SMS in PhyML based on the Bayesian Information Criterion (BIC); Lefort et al., 2017), no preset starting tree and 1000 bootstrap pseudo-replicates to assess nodal support. bPTP was run on the web server (https://species.h-its.org/ptp/) using the default settings $(100,000 \mathrm{MCMC}$ generations, thinning $=100$, burn-in value $=0.1$, seed $=123)$. For the GMYC analysis, an ultrametric tree was inferred in BEAST v.2.6.3 (Bouckaert et al., 2019). The MCMC chain was run for 10 million generations ( sampling frequency $=5000$ ) employing the HKY model, a strict molecular clock and a birth-death tree prior. ESS values (all $>200$ ) were checked with Tracer v1.7 (Rambaut et al., 2018). TreeAnnotator v2.6.3 (part of the BEAST2 package) was used to infer a maximum clade credibility tree from the set of posterior trees. GMYC was run on the web server (https://species.h-its.org/gmyc/) with the single threshold option. The bGMYC analysis was conducted on 501 posterior trees from the BEAST analysis and run $(\mathrm{MCMC}=50,000$; burnin = 40,000; thinning = 100) in R v3.6.0 (R Core Team, 2013) using the package bGMYC v.1.0.2 (Reid \& Carstens, 2012). We used a rather conservative posterior probability threshold (posterior probability: $0.5<\mathrm{P}<0.9$ ) to identify putative species, compared to higher thresholds that might overestimate the species' number (Kornilios et al., 2020).

Furthermore, we calculated the number of haplotypes (h), the haplotype diversity (Hd) and the nucleotide diversity (PiT) for the whole dataset using DnaSP v6 (Rozas et al., 2017) Finally, a statistical maximum parsimony network was inferred using TCS (Clement et al., 2002) with default settings as implemented in PopART v.1.7 (Leigh \& Bryant, 2015) to visualize phylogeographic relationships. The input file was created using a custom-made python script (available on https://github.com/maxwagn/popart_popprep). 


\section{Results}

162

163

164

165

166

167

168

169

170

171

172

173

174

175

176

177

178

179

180

181

182

183

184

185

186

187

188

189

190

191

192

193

194

195

196

197

198

Morphological determination resulted in one $B$. hyemalis and 28 B. westwoodi males and one $B$. hyemalis and 37 B. westwoodi females (Fig. 1, Fig. 2, Table 1).

The investigated morphological characters in males showed different degrees of variation between the specimens. TAs, which have been regarded as reliable for species discrimination, were anvil-shaped in all except one (294) Boreus males, resembling one of the 12 forms presented in Fig. 1T-EE. Among the different anvil shapes, little to no geographical pattern became obvious as for example all males from Hochwechsel share the same TA shape, but this particular shape was also recovered from males from Weinebene and Gösting. Some of the shapes recovered from Austrian samples also resembled the forms 35-39 (Fig. 1O-S), which Kreithner (2001) referred to as taxonomically uncertain. Similar results were also obtained for the shape of the GS, which generally appeared much more slender in $B$. westwoodi. Only the $B$. hyemalis male (294) showed a distinctly different form of the GS with a bulkier appearance and a longer medituberculus (Table 1), all B. westwoodi males regardless of their sampling location shared the same GS shape. The number of antennal segments, the number of bristles on the outer side of the front wing and the shape of the EA, all considered as unreliable characters (Kreithner 2001), did neither correlate with the two species nor with geographical origins. Characters of the ovipositor like the ventral membranous part or the lateral tapering were remarkably homogenous among all $B$. westwoodi females and similar to $B$. hyemalis. The only difference between $B$. westwoodi and $B$. hyemalis females was the breadth of the proximal part of the gonocoxosternites, which was broader in $B$. hyemalis. However, since we only have one nominal $B$. hyemalis female included in our study, we are cautious to rely on this character as we cannot estimate the extent of plasticity.

DNA barcodes of the partial COI gene ranging from 649 to $657 \mathrm{bp}$ in length were generated for 67 specimens (sequences are available on BOLD (dx.doi.org/10.5883/DS-BOREUS) and GenBank (MW627590 - MW627656). These sequences were grouped into seven BINs (Fig. 3, 4), four of which were newly created (BOLD:AEF6177, BOLD:AEF6178, BOLD:AEF6179 and BOLD:AEF8503). The different BINs, however, cannot be distinguished morphologically from each other, except for the BOLD:ACT2769, which comprises B. hyemalis. Based on the results of the DNA barcoding, Boreus westwoodi turned out to be paraphyletic with respect to $B$.

hyemalis (Fig 3, Suppl. Fig. 1). As we only had two B. hyemalis, the actual extent of intraspecific K2P distance within this species cannot be discussed here. However, since both specimens were from the same sampling site, the observed intraspecific distance was expectedly low. Intraspecific distances within $B$. westwoodi (up to $7.21 \%$ ) in part considerably exceeded interspecific distances (2.53 -5.9\%). Species delimitation analysis results differed considerably among the four alternative methods. While ABGD inferred four species in the recursive approach including the outgroup (three species in the initial approach, Suppl. Fig. 2) and GMYC suggested six species, bPTP estimated 19 to 44 (mean 28) and bGMYC resulted in 10 species, 
199

200

201

202

203

204

205

206

207

208

209

210

211

212

213

214

215

216

217

218

219

220

221

222

223

224

225

226

227

228

229

230

231

232

233

234

235

236

237

238

when assuming a threshold $0.5<\mathrm{P}<0.9$ for conspecificity (Fig. 3). Overall, we found 55 haplotypes $(\mathrm{h})$ across the whole dataset $(\mathrm{Hd}=0.99394$, $\mathrm{PiT}=0.03362)$.

The statistical maximum parsimony network revealed some phylogeographic structure and very

little haplotype sharing among and even within sampling sites. Even though geographically close sampling sites often group together in the network, there are some exceptions to this pattern (Fig. 5). Thus, the samples from Hochwechsel resulted in a part of the network (and tree, Fig. 3) that otherwise comprises samples collected west of the Mur River. On the other hand, all samples from Gösting, which is geographically close to Thal (distance $<3 \mathrm{~km}$ ) and west of the Mur River, grouped with samples north and east of the Mur River, even though they formed a quite distinct cluster there. Interestingly, the $B$. westwoodi lineage most closely related to $B$. hyemalis showed a pattern different from the rest of $B$. westwoodi, i.e., haplotype sharing was found among geographically distant sampling sites and the overall genetic diversity in this clade was low.

\section{Discussion}

In this study, we provide 67 new DNA barcodes representing the first genetic insights into the snow scorpionfly diversity of the genus Boreus from Austria and thus also Europe. This apparent lack of genetic information may be attributed to a certain characteristic of the boreids' biology. Due to their shift in seasonality of the imaginal stage to the winter months, few entomologists ever collect them as bycatch from passive stationary traps, let alone actively pursue them (Hågvar and Østbye, 2011). Consequently, contemporary literature about Boreidae almost exclusively only covers new records (Tillier et al., 2011; Ibrahimi et al., 2018), re-evaluates national distribution of species (Devetak, 1988; Finch 1997; Raemakers \& Kleukers, 1999; Tillier et al., 2011; Hågvar \& Østbye, 2011) and conducts morphological comparison of already available material (Kreithner 2001). However, phenotypic plasticity has been found to be extensive both within species and across larger geographic distances and has fueled debates about the validity and exact distribution of extant species (Willmann, 1978; Kreithner 2001). Nonetheless, certain morphological traits have been reported to hold sufficient discriminative power and suggested the presence of Boreus hyemalis and Boreus westwoodi throughout Central Europe (Kreithner, 2001, Hågvar \& Østbye 2011; Ibrahimi et al., 2018) and consequently also in Austria. However, examination of these characters on material from Austria also recovered a high degree of morphological variation at least within B. westwoodi (Fig. 1, Table 1).

Comparison of the Austrian material with morphological characteristics reported for European Boreus by Kreithner (2001) showed that some of the different morphotypes are very similar between the Austrian and the European samples, indicating a large diversity even within Austria. Furthermore, the resemblance of some of the Austrian TA shapes with the forms regarded as taxonomically uncertain by Kreithner (2001) potentially hints at the existence of cryptic species. The morphological variation, though, is not perfectly consistent with the distribution of genetic haplotypes as samples from the same location might share similar DNA barcodes but show different morphologies or vice versa (Table 1, Fig. 1, Fig. 5), similar to patterns previously reported for some other arthropods, such as scorpions of the genus Buthus in the Atlas Mountains 
239 or North African darkling beetles (Habel et al., 2012; Husemann et al., 2012; Rangel López et al. 240 2018). Since only one single male (sample 294) could be assigned to B. hyemalis based on 241 synoptic inspection of all morphological characters, phenotypic plasticity cannot be evaluated 242 here. However, the shape of TA recovered for sample 294 matches form 34 of Kreithner (2001) 243 almost perfectly (Fig. 1N) and for the first time links this particular morphotype with a DNA 244 barcode and a particular BIN (BOLD:ACT2769). In females, morphological variability, i.e. 245 ovipositor shape, was virtually non-existent. The sole exception was the female individual 246 collected at Zirbitzkogel, the locality where we also collected a B. hyemalis male. Though 247 morphologically similar to other females, this individual had a broader ovipositor than other 248 specimens and, unlike any other specimen, lateral extensions at the proximal part of the 249 250 251

252

253

254

255

256

257

258

259

260

261

262

263

264

265

266

267

268

269

270

271

272

273

274

275

276

277

278

gonocoxosternites (compare with Kreithner, 2001). These few findings of B. hyemalis are also in line with Kreithner (2001), who reported Boreus populations across Austria being predominantly B. westwoodi with only a few reports of B. hyemalis from Eastern Austria. Kreithner (2001) also indicated, that reports of sympatric occurrences may reflect cases of misidentification and that additional species could be present, e.g. in alpine regions.

Furthermore, the results of the DNA barcoding and species delimitation analyses suggest that there might be more than two species of Boreus present in Austria (Fig. 3). As we had only two nominal specimens of $B$. hyemalis included in our dataset, no inferences can be drawn about intraspecific genetic diversity or the presence/absence of a barcoding gap. In B. westwoodi, maximum intraspecific distances are significantly higher than the distance to their nearest neighbor (Table 2), which has also been reported for e.g. ground beetles, butterflies and aphids (Raupach et al., 2016; Janzen et al., 2017; Lee et al., 2017) and may be an indication for cryptic diversity. Furthermore, interspecific distances of two to three percent separating good species have previously been found in e.g., aphids and mosquitos as well (Lee et al., 2017; Wang et al., 2012). While distance-based species delimitation methods like ABGD are prone to lump many species together (da Silva et al. 2018; Dellicour \& Flot, 2018; Galimberti et al., 2020) and Dellicour and Flot (2015) even report ABGD and GMYC as unable to correctly delimit species in scenarios involving only one or two species, ABGD suggested one additional species for Austrian boreids. Tree-based methods on the other hand are known to have a tendency for oversplitting, both in cases with few and many species (Dellicour and Flot, 2018), which would explain the large number of species suggested by bGMYC and bPTP in our case. However, despite a general incongruence and a large range in the number of potentially recovered species with the different methods (Fig. 3), they all concur in suggesting that more than the two previously reported species exist in Austria. Limitations for species delimitation inferences based on a single gene are obvious and well discussed in literature but still can pinpoint ambiguous cases (da Silva et al., 2018; Galimberti et al., 2020). However, in the case of Austrian Boreus, the patterns obtained from DNA barcoding, species delimitation, statistical maximum parsimony network and morphological analyses do indicate potential cryptic diversity.

Besides potential cryptic diversity, we found a remarkable geographic structure, with distinct haplogroups present in geographically close populations, sometimes only a few kilometers apart.

PeerJ reviewing PDF | (2021:01:57210:2:0:NEW 16 Apr 2021) 
279 Even though our sample comprises only a few animals per location, the general lack of haplotype 280 sharing among most sampling sites (with a few exceptions) is striking, and the large number of 281 singletons indicates large (effective) population sizes. Assuming a general range of arthropod 282 COI divergence rates of 1.0-2.5\% per MY (e.g. Brower 1994; Quek et al., 2004; Papadopoulou 283 et al., 2010; Pons et al., 2010), the observed pairwise distances among main lineages of $\sim 2.5-$ $2847.2 \%$ translate into divergence times of $\sim 1-2.5$ to $2.9-7.2$ MY. As Boreus spp. are flightless, 285 some phylogeographic structure was expected, even considering the rather small geographic 286 scope of our study. Yet, the extent of structure is surprising and unexpected, even though in 287 general, flightless and/or less mobile taxa show higher levels of population genetic differentiation than good dispersers (Papadopoulou et al., 2009). Previous studies on small flightless arthropods with alleged low dispersal ability found varying patterns, from little phylogeographic structure with haplotype sharing across long distances (e.g., oribatid mites of the genus Cymbaeremaeus, Schäffer et al., 2019) to deeply divergent genetic lineages without gene flow, potentially representing cryptic species, across distances of only tens of kilometers (e.g., springtails of the genus Lepidocyrtus, Ciccionardi et al., 2010). The patterns observed in Austrian Boreus fit this latter extreme (disregarding the $B$. westwoodi haplogroup most closely related to $B$. hyemalis that was shared among some samples from distant localities). In addition,

296

297

298

299

300

301

302

303

304

305

306

307

308

309

310

311

312

313

314

315

316

317

318 the factors and processes underlying the peculiar phylogeographic pattern observed in Austrian Boreus remain unclear, but it appears that Boreus are indeed rather stationary and do not generally disperse over larger distances.

\section{Conclusions}

In conclusion, this study presents the first genetic information on the genus Boreus in Austria, and consequently also Europe. Furthermore, it provides several new localities from which boreids have not been reported within Austria so far and thus augments their known distribution range in Austria. DNA barcodes linked to different morphotypes prove the presence of Boreus westwoodi and Boreus hyemalis in Austria, high levels of phylogeographic structure on small geographic scales, and indicate the potential presence of further cryptic species. The phenotypic plasticity previously reported for these two species is confirmed in the present study as several morphological characters show a large variation that does not correlate with genetic variation. Seven distinct BINs were recovered by BOLD and several, albeit inconsistent, potential species were suggested across the alternative species delimitation analyses. This potential cryptic diversity probably also extends to other European populations of Boreus but disentangling the exact number of species, possible (ancient) hybridization/introgression, (lack of) gene flow among localities and the precise distribution of these species will require further multilocus or genomic as well as morphological investigations and a pan-European sampling of boreids.

\section{Acknowledgements}

We are grateful to Lukas Strohmaier, Barbara Bernhart, Thomas Bernhart and Christian Komposch for their help in sample collection. Furthermore, we would like to thank Martin 
319 Husemann and two other anonymous reviewers for their constructive comments which helped to 320 improve this manuscript.

321

322

323

324

325

326

327

328

329

330

331

332

333

334

335

336

337

338

339

340

341

342

343

344

345

346

347

348

349

350

351

352

353

354

355

356

357

\section{References}

Alexander, A. M., Su, Y. C., Oliveros, C. H., Olson, K. V., Travers, S. L., Brown, R. M. (2017). Genomic data reveals potential for hybridization, introgression, and incomplete lineage sorting to confound phylogenetic relationships in an adaptive radiation of narrow-mouth frogs. Evolution, 71(2), 475-488. https://doi.org/10.1111/evo.13133

Baack, E. J., \& Rieseberg, L. H. (2007). A genomic view of introgression and hybrid speciation. Current Opinion in Genetics \& Development, 17(6), 513-518.

https://doi.org/10.1016/j.gde.2007.09.001

Blades, D. C. (2002). A new species of Boreus (Mecoptera: Boreidae) from Vancouver Island, British Columbia. Journal of the Entomological Society of British Columbia, 99, 133-140.

Bouckaert R., Vaughan T.G., Barido-Sottani J., Duchêne S., Fourment M., Gavryushkina A., ... \& Drummond, A. J. (2019). BEAST 2.5: An advanced software platform for Bayesian evolutionary analysis. PLoS Computational Biology, 15(4), e1006650.

https://doi.org/10.1371/journal.pcbi.1006650

Brauer, F. (1876). Die Neuropteren Europas und insbesondere Österreichs. - Festschrift der kaiserlich königlichen Zoologisch-botanischen Gesellschaft: 263-300. - Wien.

Brower, A. V. (1994). Rapid morphological radiation and convergence among races of the butterfly Heliconius erato inferred from patterns of mitochondrial DNA evolution. Proceedings of the National Academy of Sciences USA, 91(14), 6491-6495.

https://doi.org/10.1073/pnas.91.14.6491

Ciccionardi, F., Nardi, F., Emerson, B. C., Frati, F., Fanciulli, P. P. (2010). Deep

phylogeographic divisions and long-term persistence of forest invertebrates (Hexapoda:

Collembola) in the North-Western Mediterranean basin. Molecular Ecology, 19(2), 386-400.

https://doi.org/10.1111/j.1365-294X.2009.04457.x

Clement, M., Snell, Q., Walke, P., Posada, D., Crandall, K. (2002). TCS: estimating gene genealogies. Proceedings of the16th International Parallel and Distributed Processing Symposium 2,184.

Cong, Q., Shen, J., Borek, D., Robbins, R. K., Opler, P. A., Otwinowski, Z., Grishin, N. V. (2017). When COI barcodes deceive: complete genomes reveal introgression in hairstreaks.

Proceedings of the Royal Society B: Biological Sciences, 284(1848), 20161735.

https://doi.org/10.1098/rspb.2016.1735

da Silva, R., Peloso, P. L., Sturaro, M. J., Veneza, I., Sampaio, I., Schneider, H., Gomes, G.

(2018). Comparative analyses of species delimitation methods with molecular data in snappers (Perciformes: Lutjaninae). Mitochondrial DNA Part A, 29(7), 1108-1114.

https://doi.org/10.1080/24701394.2017.1413364 
358 Dellicour, S., \& Flot, J. F. (2018). The hitchhiker's guide to single-locus species delimitation.

359 Molecular Ecology Resources, 18(6), 1234-1246. https://doi.org/10.1111/1755-0998.12908

360 Devetak, D. (1988). The distribution of scorpionflies (Mecoptera, Insecta) in Slovenia=

361 Razširjenost kljunavcev (Mecoptera, Insecta) v Sloveniji. BV, 36(2), 1-12.

362 Duftner, N., Koblmüller, S., Sturmbauer, C. (2005). Evolutionary relationships of the

363 Limnochromini, a tribe of benthic deepwater cichlid fish endemic to Lake Tanganyika, East

364 Africa. Journal of Molecular Evolution 60, 277-289. DOI https://doi.org/10.1007/s00239-004-

$365 \underline{0017-8}$

366 Ermakov, O. A., Simonov, E., Surin, V. L., Titov, S. V., Brandler, O. V., Ivanova, N. V.,

367 Borisenko, A. V. (2015). Implications of hybridization, NUMTs, and overlooked diversity for

368 DNA barcoding of Eurasian ground squirrels. PLoS One, 10(1), e0117201.

369 https://doi.org/10.1371/journal.pone.0117201

370 Finch, O. D. (1997) Zum Vorkommen des Winterhaftes Boreus hiemalis L (Insecta: Mecoptera)

371 im nordwestlichen Niedersachsen. Drosera (2), 113-116.

372 Galimberti, A., Assandri, G., Maggioni, D., Ramazzotti, F., Baroni, D., Bazzi, G., ... \& Ilahiane,

373 L. (2020). Italian odonates in the Pandora's box: A comprehensive DNA barcoding inventory

374 shows taxonomic warnings at the Holarctic scale. Molecular Ecology Resources, 21(8), 183-200.

375 https://doi.org/10.1111/1755-0998.13235

376 Gepp, J. (1982). Die Mecopteren Kärntens mit Bemerkungen über Lautäußerungen von Bittacus

377 italicus (MÜLLER). Carinthia II 172(92), 341-350

378 Gruppe, A., \& Aistleitner, U. (2011). Beitrag zur Kenntnis der Arteninventare und ökologischen

379 Ansprüche der Netzflügler (Neuropterida) und Skorpionsfliegen (Mecoptera) in Vorarlberg,

380 Austria occ. inatura - Forschung online. 1, 1-8

381 Guindon, S, Dufayard, J. F., Lefort, V., Anisimova, M., Hordijk, W., Gascuel, O. (2010) New

382 algorithms and methods to estimate Maximum-Likelihood phylogenies: Assessing the

383 performance of PhyML. Systematic Biology, 59(3), 307-321.

384 https://doi.org/10.1093/sysbio/syq010

385 Habel, J. C., Husemann, M., Schmitt, T., Zachos, F. E., Honnen, A. C., Petersen, B., ... \& Stathi,

386 I. (2012). Microallopatry caused strong diversification in Buthus scorpions (Scorpiones:

387 Buthidae) in the Atlas Mountains (NW Africa). PloS One, 7(2), e29403.

388 https://doi.org/10.1371/journal.pone.0029403

389 Hågvar, S. (2001). Occurrence and migration on snow, and phenology of egg-laying in the

390 winter-active insect Boreus sp. (Mecoptera). Norwegian Journal of Entomology, 48, 51-60.

391 Hågvar, S. (2010). A review of Fennoscandian arthropods living on and in snow. European

392 Journal of Entomology, 107(3), 281.

393 Hågvar, S., \& Østbye, E. (2011). Distribution of Boreus westwoodi Hagen, 1866 and Boreus

394 hyemalis (L., 1767) (Mecoptera) in Norway. Norwegian Journal of Entomology, 58, 73-80.

395 Haring, E., Sattmann, H., Szucsich, N. U. (2015). ABOL als Biodiversitätsnetzwerk-Struktur und

396 Ziele taxonspezifischer Cluster. Acta ZooBot Austria, 152, 149-156. 
397 Hebert, P. D., Ratnasingham, S., De Waard, J. R. (2003). Barcoding animal life: cytochrome c 398 oxidase subunit 1 divergences among closely related species. Proceedings of the Royal Society 399 of London. Series B: Biological Sciences, 270(suppl_1), S96-S99.

400 https://doi.org/10.1098/rsbl.2003.0025

401 Hernández-Triana, L. M., Prosser, S. W., Rodríguez-Perez, M. A., Chaverri, L. G., Hebert, P. D. 402 N., Ryan Gregory, T. (2014). Recovery of DNA barcodes from blackfly museum specimens 403 (Diptera: Simuliidae) using primer sets that target a variety of sequence lengths. Molecular 404 Ecology Resources, 14(3), 508-518. https://doi.org/10.1111/1755-0998.12208

405

406

407

408

409

410

411

412

413

414

415

416

417

418

419

420

421

422

423

424

425

426

427

428

429

430

431

432

433

434

435

Huemer, P., Wieser, C., Stark, W., Hebert, P. D., Wiesmair, B. (2019). DNA barcode library of megadiverse Austrian Noctuoidea (Lepidoptera)-a nearly perfect match of Linnean taxonomy. Biodiversity Data Journal, 7. https://doi.org/10.3897/BDJ.7.e37734

Husemann, M., Schmitt, T., Stathi, I., \& Habel, J. C. (2012). Evolution and radiation in the scorpion Buthus elmoutaouakili Lourenco and Qi 2006 (Scorpiones: Buthidae) at the foothills of the Atlas Mountains (North Africa). Journal of Heredity, 103(2), 221-229.

https://doi.org/10.1093/jhered/esr130

Ibrahimi, H., Devetak, D., Pizzigalli, C., Hoxha, L. (2018). First record of the genus Boreus Latreille, 1816 from the Republic of Kosovo. Spixiana 41(1), 12

Janzen, D. H., Burns, J. M., Cong, Q., Hallwachs, W., Dapkey, T., Manjunath, R., ... \& Grishin, N. V. (2017). Nuclear genomes distinguish cryptic species suggested by their DNA barcodes and ecology. Proceedings of the National Academy of Sciences, 114(31), 8313-8318.

https://doi.org/10.1073/pnas.1621504114

Kehlmaier, C., Zhang, X., Georges, A., Campbell, P. D., Thomson, S., Fritz, U. (2019).

Mitogenomics of historical type specimens of Australasian turtles: clarification of taxonomic confusion and old mitochondrial introgression. Scientific reports, 9(1), 1-12.

https://doi.org/10.1038/s41598-019-42310-x

Koblmüller, S., Salzburger, W., Obermüller, B., Eigner, E., Sturmbauer, C., Sefc, K. M. (2011)

Separated by sand, fused by dropping water: habitat barriers and fluctuating water levels steer the evolution of rock-dwelling cichlid populations. Molecular Ecology, 20(11), 2272-2290. https://doi.org/10.1111/j.1365-294X.2011.05088.x

Kornilios, P., Jablonski, D., Sadek, R. A., Kumlutas, Y., Olgun, K., Avci, A., Ilgaz, C. (2020). Multilocus species-delimitation in the Xerotyphlops vermicularis (Reptilia: Typhlopidae) species complex. Molecular Phylogenetics and Evolution 152, 106922

https://doi.org/10.1016/j.ympev.2020.106922

Kreithner, A. (2001). Über Boreus-Arten aus den Alpen: Taxonomische Charakterisierung und Verbreitung (Insecta, Mecoptera, Boreidae). Berichte des naturwissenschaftlich-medizinischen Vereins in Innsbruck, 88, 213-236.

Lee, Y., Lee, W., Kanturski, M., Foottit, R. G., Akimoto, S. I., Lee, S. (2017). Cryptic diversity of the subfamily Calaphidinae (Hemiptera: Aphididae) revealed by comprehensive DNA barcoding. Plos one, 12(4), e0176582. https://doi.org/10.1371/journal.pone.0176582

PeerJ reviewing PDF | (2021:01:57210:2:0:NEW 16 Apr 2021) 
436 Lefort, V., Longueville, J.E., Fascuel, O. (2017) SMS: Smart model selection in PhyML.

437 Molecular Biology and Evolution, 34(9), 2422-2424. https://oi.org/10.1093/molbev/msx149

438 Leigh, J.W., Bryant, D. (2015). PopART: Full-feature software for haplotype network

439 construction. Methods in Ecology and Evolution 6(9), 1110-1116. https://doi.org/10.1111/2041-

$440 \quad \underline{210 X .12410}$

441 Liu, J., Jiang, J., Song, S., Tornabene, L., Chabarria, R., Naylor, G. J. P., Li, C. (2017).

442 Multilocus DNA barcoding - species identification with multilocus data. Scientific Reports, 7,

443 16601. https://doi.org/10.1038/s41598-017-16920-2

444 Mayer, K. (1938): Boreus in der Cechoslovakei. — Entomologické listy, 2, 129-140

445 Papadopoulou, A., Anastasiou,I., Keskin, B., Vogler, A. P. (2009). Comparative phylogeography

446 of tenebrionid beetles in the Aegean archipelago: the effect of dispersal ability and habitat

447 preference. Molecular Ecology, 18(11), 2503-2517. https://doi.org/10.1111/j.1365-

$448 \quad$ 294X.2009.04207.x

449 Papadopoulou, A., Anastasiou, I., Vogler, A. P. (2010). Revisiting the insect mitochondrial

450 molecular clock: the mid-Aegean trench calibration. Molecular Biology and Evolution, 27(7),

451 1659-1672. https://doi.org/10.1093/molbev/msq051

452 Pons, J., Ribera, I., Bertranpetit, J., Balke, M. (2010). Nucleotide substitution rates for the full set 453 of mitochondrial protein-coding genes in Coleoptera. Molecular Phylogenetics and Evolution,

454 56(2), 796-807. https://doi.org/10.1016/j.ympev.2010.02.007Quek, S.-P., Davies, S. J., Itino, T.,

455 Pierce, N. E. (2004). Codivergence in an ant-plant mutualism: stem texture and the evolution of

456 host use in Crematogaster (Formicidae: Myrmicinae) inhabitants of Macaranga

457 (Euphorbiaceae). Evolution, 58(3), 554-570. https://doi.org/10.1111/j.0014-3820.2004.tb01678.x

458 Paill, W., Koblmüller, S., Frieß, T., Gereben-Krenn, B.-A., Mairhuber, C., ... \& Zangl, L.

459 (2021). Relicts from glacial times: The ground beetle Pterostichus adstrictus Eschscholtz, 1823

460 (Coleoptera: Carabidae) in the Austrian Alps. Insects, 12, 84.

461 https://doi.org/10.3390/insects12010084

462 Penny, N. (1977). A systematic study of the family Boreidae (Mecoptera). The University of

463 Kansas Science Bulletin, 51(5), 141-217.

464 Puillandre, N., Lambert, A., Brouillet, S., Achaz, G. (2011). ABGD, Automatic Barcode Gap

465 Discovery for primary species delimitation, Molecular Ecology, 21(8), 1864-1877.

466 https://doi.org/10.1111/j.1365-294X.2011.05239.x

467 Raemakers, I., Kleukers, R. M. J. C. (1999). De sneeuwspringer Boreus hyemalis in Nederland

468 (Mecoptera: Boreidae). Nederlandse Faunistische Mededelingen, 8, 1-10.

469 Rambaut, A., Drummond, A. J., Xie, D., Baele, G., Suchard, M. A. (2018) Posterior

470 summarisation in Bayesian phylogenetics using Tracer 1.7. Systematic Biology, 76(5), 901-904.

471 https://doi.org/10.1093/sysbio/syy032

472 Rangel López, J. Á., Husemann, M., Schmitt, T., Kramp, K., \& Habel, J. C. (2018). Mountain

473 barriers and trans-Saharan connections shape the genetic structure of Pimelia darkling beetles

474 (Coleoptera: Tenebrionidae). Biological Journal of the Linnean Society, 124(3), 547-556.

475 https://doi.org/10.1093/biolinnean/bly053 
476 Ratnasingham, S., Hebert, P. D. N. (2007). BOLD: The Barcode of Life Data System

477 (www.barcodinglife.org). Molecular Ecology Notes, 7(3), 355-364.

478 https://doi.org/10.1111/j.1471-8286.2007.01678.x

479 Ratnasingham, S., Hebert, P. D. N. (2013). A DNA-based registry for all animal species: The

480 Barcode Index Number (BIN) system. PLoS One, 8(8), e66213.

481 https://doi.org/10.1371/journal.pone.0066213

482 Raupach, M. J., Hannig, K., Moriniere, J., Hendrich, L. (2016). A DNA barcode library for 483 ground beetles (Insecta, Coleoptera, Carabidae) of Germany: The genus Bembidion Latreille, 4841802 and allied taxa. ZooKeys, (592), 121. doi: 10.3897/zookeys.592.8316

485 Reid, N. M., Carstens, B. C. (2012). Phylogenetic estimation error can decrease the accuracy of 486 species delimitation: a Bayesian implementation of the general mixed Yule-coalescent model.

487 BMC Evolutionary Biology, 12(1), 196. https://doi.org/10.1186/1471-2148-12-196

488 R Core Team. (2013). R: A language and environment for statistical computing. (Vienna,

489 Austria: R Foundation for Statistical Computing) http://www.R-project.org/

490 Saure, C. (2003). Verzeichnis der Schnabelfliegen (Mecoptera) Deutschlands. Entomofauna

491 Germanica, 6, 299-303.

492 Schäffer, S., Kerschbaumer, M., Koblmüller, S. (2019). Multiple new species: Cryptic diversity

493 in the widespread mite species Cymbaeremaeus cymba (Oribatida, Cymbaeremaeidae).

494 Molecular Phylogenetics and Evolution, 135, 185-192.

495 https://doi.org/10.1016/j.ympev.2019.03.008

496 Sikes, D. S., Bowser, M., Morton, J. M., Bickford, C., Meierotto, S., Hildebrandt, K. (2017).

497 Building a DNA barcode library of Alaska's non-marine arthropods. Genome, 60(3), 248-259.

498 https://doi.org/10.1139/gen-2015-0203

499 Tamura, K., Stecher, G., Peterson, D., Filipski, A., Kumar, S. (2013). MEGA6: Molecular

500 Evolutionary Genetics Analysis version 6.0. Molecular Biology and Evolution 30, 2725-2729.

501 https://doi.org/10.1093/molbev/mst197

502 Taylor, S. A., \& Larson, E. L. (2019). Insights from genomes into the evolutionary importance

503 and prevalence of hybridization in nature. Nature ecology \& evolution, 3(2), 170-177.

504 https://doi.org/10.1038/s41559-018-0777-y

505 Tillier, P., Callot, H., Ragué, J. C. (2011). Contribution à la connaissance de Boreus hyemalis L., 5061767 en France (Neomecoptera Boreidae). L'Entomologiste, 67(5), 251-255.

507 Trewick, S. A. (2008). DNA Barcoding is not enough: mismatch of taxonomy and genealogy in

508 New Zealand grasshoppers (Orthoptera: Acrididae). Cladistics, 24(2), 140-254.

509 https://doi.org/10.1111/j.1096-0031.2007.00174.x

510 van Velzen, R., Weitschek, E., Felici, G., Bakker, F. T. (2012). DNA barcoding of recently

511 diverged species: relative performance of matching methods. PloS One, 7(1), e30490.

512 https://doi.org/10.1371/journal.pone.0030490

513 Wang, G., Li, C., Guo, X., Xing, D., Dong, Y., Wang, Z., ... \& Zhu, X. (2012). Identifying the

514 main mosquito species in China based on DNA barcoding. PLoS One, 7(10), e47051.

515 https://doi.org/10.1371/journal.pone.0047051 
516 Willmann, R. (1978). Redeskription von Boreus gigas Brauer (Boreidae, Mecoptera), zugleich 517 ein Beitrag zur Variabilität von B. hyemalis (L.). Annalen des Naturhistorischen Museums in 518 Wien, 525-532.

519 Zangl, L., Kunz, G., Berg, C., Koblmüller, S. (2019). First records of the parthenogenetic 520 Surinam cockroach Pycnoscelus surinamensis (Insecta: Blattodea: Blaberidae) for Central

521 Europe. Journal of Applied Entomology, 143(3), 308-313. https://doi.org/10.1111/jen.12587

522 Zangl, L., Daill, D., Schweiger, S., Gassner, G., Koblmüller, S. (2020). A reference DNA

523 barcode library for Austrian amphibians and reptiles. PloS One, 15(3), e0229353.

524 https://doi.org/10.1371/journal.pone.0229353

525 Zhang, J., Kapli, P., Pavlidis, P., Stamatakis, A. (2013). A general species delimitation method 526 with applications to phylogenetic placements. Bioinformatics, 29(22), 2869-2876.

527 https://doi.org/10.1093/bioinformatics/btt499 


\section{Table $\mathbf{1}$ (on next page)}

Morphological characterization of Austrian male Boreus spp.

Morphological characterization of male Boreus spp. according to Kreithner (2001). Numbers in Field ID correspond with supplementary table 1. Tergal apophyses (TA), epiandrum (EA), gonostylus (GS). Numbers in GS correspond to figures in Kreithner (2001). Forms of TA correspond with figure $1(\mathrm{~T}-\mathrm{EE})$. 


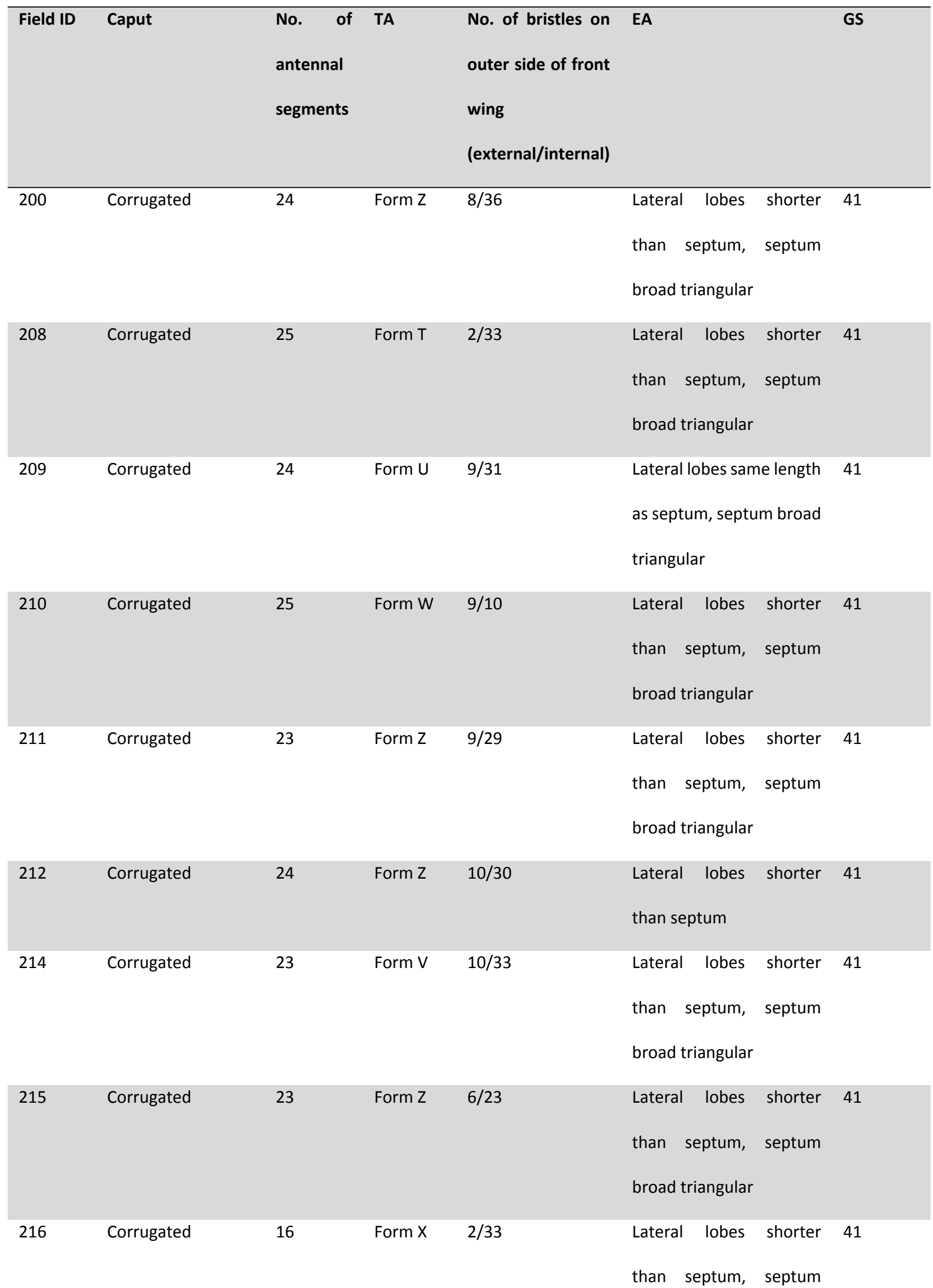




\begin{tabular}{|c|c|c|c|c|c|c|}
\hline & & & & & broad triangular & \\
\hline 265 & Corrugated & 25 & Form AA & $11 / 33$ & $\begin{array}{l}\text { Lateral lobes shorter } \\
\text { than septum, septum } \\
\text { broad triangular }\end{array}$ & 41 \\
\hline 266 & Smooth, pilose & & Form AA & $9 / 28$ & $\begin{array}{l}\text { Lateral lobes shorter } \\
\text { than septum, flat, } \\
\text { septum broad triangular }\end{array}$ & 41 \\
\hline 267 & Corrugated & 23 & Form AA & $7 / 29$ & $\begin{array}{l}\text { Lateral lobes shorter } \\
\text { than septum, flat, } \\
\text { septum broad triangular }\end{array}$ & 41 \\
\hline 268 & Corrugated & 25 & Form AA & $13 / 36$ & $\begin{array}{l}\text { Lateral lobes shorter } \\
\text { than septum, flat, } \\
\text { septum broad triangular }\end{array}$ & 41 \\
\hline 269 & Corrugated & 23 & Form AA & $8 / 30$ & $\begin{array}{l}\text { Lateral lobes shorter } \\
\text { than septum, flat, } \\
\text { septum broad triangular }\end{array}$ & 41 \\
\hline 274 & Corrugated & 25 & Form CC & $12 / 32$ & $\begin{array}{l}\text { Lateral lobes shorter } \\
\text { than septum, septum } \\
\text { broad triangular }\end{array}$ & 41 \\
\hline 275 & Corrugated & 24 & Form AA & $9 / 32$ & $\begin{array}{l}\text { Lateral lobes longer than } \\
\text { septum, septum broad } \\
\text { triangular }\end{array}$ & 41 \\
\hline 276 & Corrugated & 23 & Form AA & $13 / 31$ & $\begin{array}{l}\text { Lateral lobes shorter } \\
\text { than septum, septum } \\
\text { broad triangular }\end{array}$ & 41 \\
\hline 277 & Corrugated & 24 & Form $\mathrm{X}$ & $11 / 26$ & $\begin{array}{l}\text { Lateral lobes longer than } \\
\text { septum, septum broad } \\
\text { triangular }\end{array}$ & 41 \\
\hline 278 & Corrugated & 23 & Form BB & $8 / 20$ & Lateral lobes shorter & 41 \\
\hline
\end{tabular}




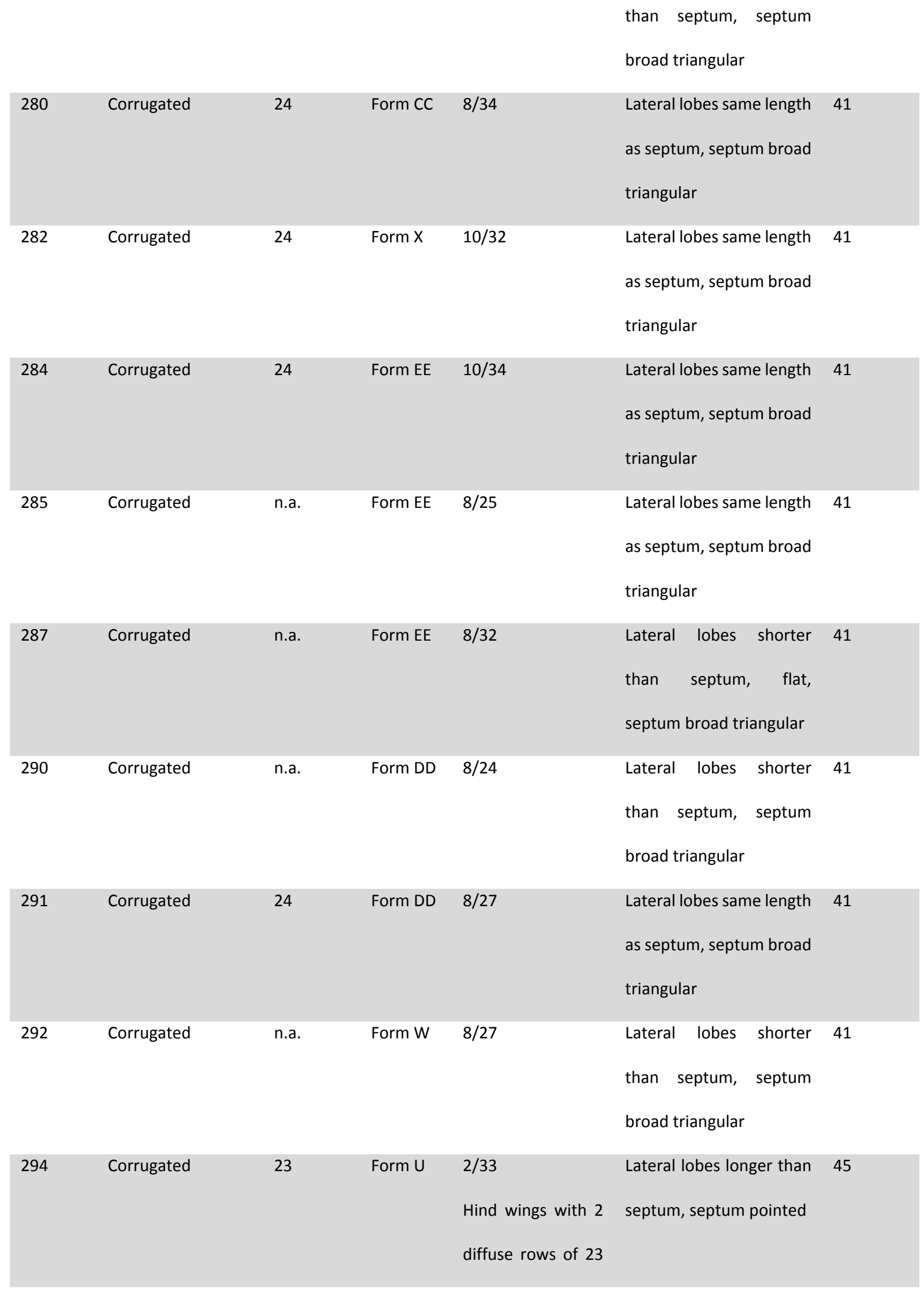




\begin{tabular}{|c|c|c|c|c|c|c|c|}
\hline & & & & bristles & & & \\
\hline 296 & Corrugated & 23 & Form AA & $11 / 26$ & $\begin{array}{l}\text { Lateral lobes } \\
\text { than septum, } \\
\text { broad triangular }\end{array}$ & $\begin{array}{l}\text { shorter } \\
\text { septum }\end{array}$ & 41 \\
\hline 297 & Corrugated & 23 & Form AA & $14 / 32$ & $\begin{array}{l}\text { Lateral lobes } \\
\text { than septum, } \\
\text { broad triangular }\end{array}$ & $\begin{array}{l}\text { shorter } \\
\text { septum }\end{array}$ & 41 \\
\hline 299 & Corrugated & 24 & Form Z & $8 / 33$ & $\begin{array}{l}\text { Lateral lobes sam } \\
\text { as septum, flat, } \\
\text { broad triangular }\end{array}$ & $\begin{array}{l}\text { le length } \\
\text { septum }\end{array}$ & 41 \\
\hline 301 & Corrugated & 25 & Form X & $10 / 39$ & $\begin{array}{l}\text { Lateral lobes } \\
\text { than septum, } \\
\text { broad triangular }\end{array}$ & $\begin{array}{l}\text { shorter } \\
\text { septum }\end{array}$ & 41 \\
\hline 303 & Corrugated & 24 & Form CC & $12 / 39$ & $\begin{array}{l}\text { Lateral lobes } \\
\text { than septum, } \\
\text { broad triangular }\end{array}$ & $\begin{array}{l}\text { shorter } \\
\text { septum }\end{array}$ & 41 \\
\hline 307 & Corrugated & 24 & Form CC & $10 / 34$ & $\begin{array}{l}\text { Lateral lobes } \\
\text { than septum, } \\
\text { broad triangular }\end{array}$ & $\begin{array}{l}\text { shorter } \\
\text { septum }\end{array}$ & 41 \\
\hline 308 & Corrugated & 24 & Form BB & $12 / 23$ & $\begin{array}{l}\text { Lateral lobes } \\
\text { than septum, } \\
\text { broad triangular }\end{array}$ & $\begin{array}{l}\text { shorter } \\
\text { septum }\end{array}$ & 41 \\
\hline 312 & Corrugated & 25 & Form Y & $10 / 34$ & $\begin{array}{l}\text { Lateral lobes } \\
\text { than septum, } \\
\text { broad triangular }\end{array}$ & $\begin{array}{l}\text { shorter } \\
\text { septum }\end{array}$ & 41 \\
\hline 314 & Corrugated & 25 & Form BB & $11 / 34$ & $\begin{array}{l}\text { Lateral lobes } \\
\text { than septum, } \\
\text { broad triangular }\end{array}$ & $\begin{array}{l}\text { shorter } \\
\text { septum }\end{array}$ & 41 \\
\hline 318 & Corrugated & 24 & Form CC & $13 / 39$ & Lateral lobes & shorter & 41 \\
\hline
\end{tabular}


than septum, septum

broad triangular

1 


\section{Table 2 (on next page)}

Genetic distances of Boreus spp. based on COI sequences.

Maximum intraspecific K2P distances $\left(\mathrm{I}_{\max }\right)$ and distances (DNN - distance to nearest neighbor) to nearest neighbor (NN) are listed. 
1

\begin{tabular}{cccc}
\hline Species & $\mathbf{I}_{\max }$ & DNN & NN \\
\hline Boreus hyemalis & 0.15 & 2.53 & Boreus westwoodi \\
Boreus westwoodi & 7.21 & 2.53 & Boreus hyemalis
\end{tabular}




\section{Figure 1}

Images and drawings of boreids and their morphological characters.

Images of a copulation (A) and a single male (B) Boreus westwoodi, as well as digital microscopy images of the anvil-shaped tergal apophyses (TA) of $B$. westwoodi (C) and pointed TA of $B$. hyemalis (D) from Austria (indicated by black arrows). (E-EE) Drawings of types of TA of $B$. westwoodi (forms E-L), B. hyemalis (forms M-N) as well as forms of uncertain taxonomic status (O-S) from across Europe (edited from Kreithner (2001)) and Austrian B. westwoodi (T-EE). Drawings of the main shapes of the genital segments (GS) with the epiandrum (EA) (FF-GG, see table 1) retrieved and edited from Kreithner (2001). $\odot$ Photos by Elisabeth Glatzhofer. 
A)

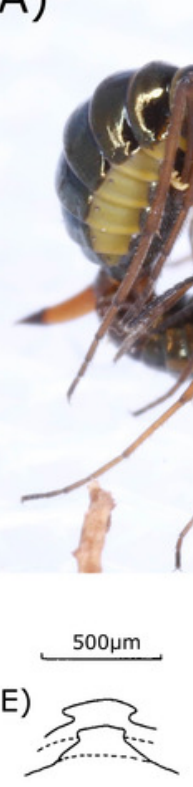

F)<smiles>C[C@@H]1CC[C@H]2C[C@@H]1CC2(C)C</smiles>

G)<smiles>c1cc2cc(c1)CC2</smiles>

H)

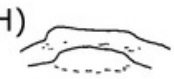

I)

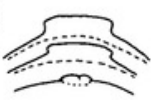

J)

K)

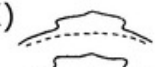

L)

M)

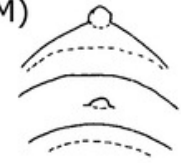

N)

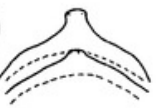

B)

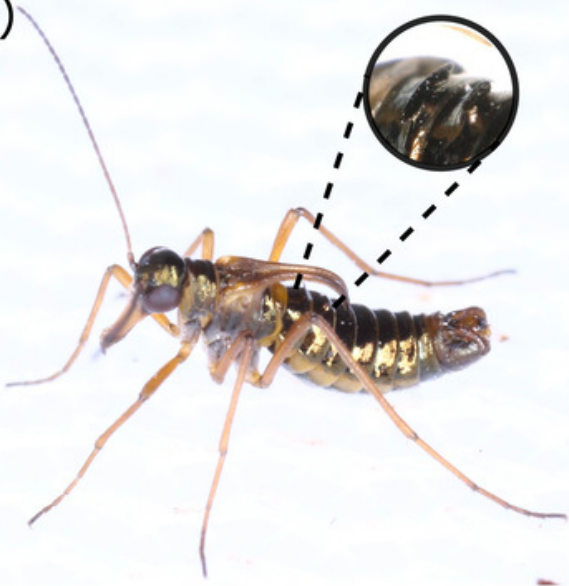

O)<smiles>CC1CCCC(C)CCC1</smiles>

P)

Q)

R)

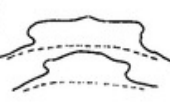

S)

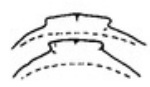

?

$\sum_{-1 \ldots}^{\mathrm{B})}$

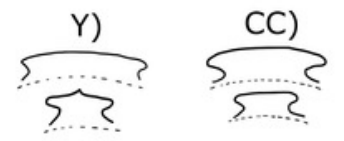<smiles>C1=CCCCCC1</smiles>

Z)

$\overbrace{2 \mathrm{DD})}^{\mathrm{D}}$

$\sum_{n=?}^{v)}$

$\sum^{w)}$

$\frac{A A)}{5 ?}$

$\overbrace{}^{\mathrm{EE})}$
C)

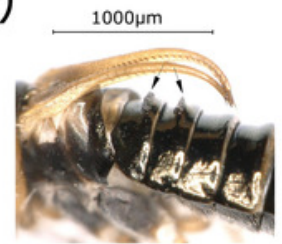

D)

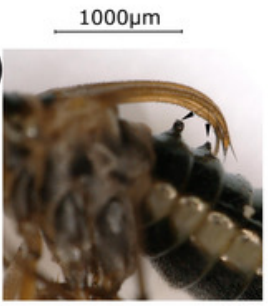

FF)

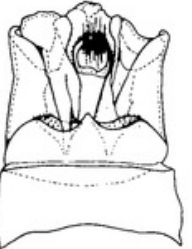

GG)

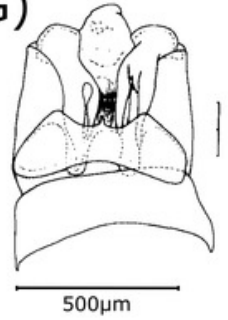




\section{Figure 2}

Images of Boreus females and their ovipositors.

Digital microscopy images of (A) Boreus westwoodi and (B) B. hyemalis females as well as the dorsal ( $C$ and $E$ ) and ventral ( $D$ and $F$ ) view on their ovipositor, respectively.
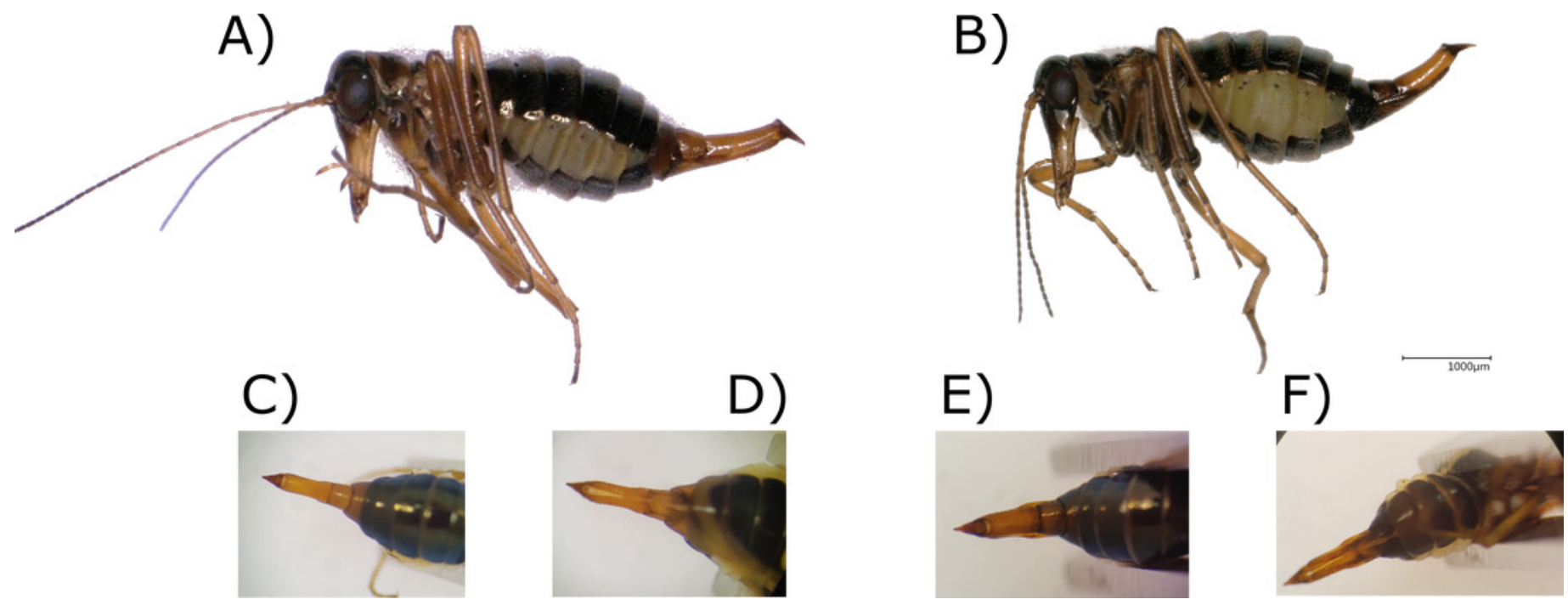


\section{Figure 3}

Bayesian inference phylogeny and species delimiation.

Bayesian Inference (BI) phylogeny based on the DNA barcoding region (part of the mitochondrial COI gene). Tip numbers correspond with table S1 and represent specimen IDs. Colored dots represent sample origin. Colored branches indicate initial morphological species assignment. Dots near nodes represent posterior probability categories. Boxes and heatmap to the right indicate the number of putative species inferred by different molecular species delimitation methods.

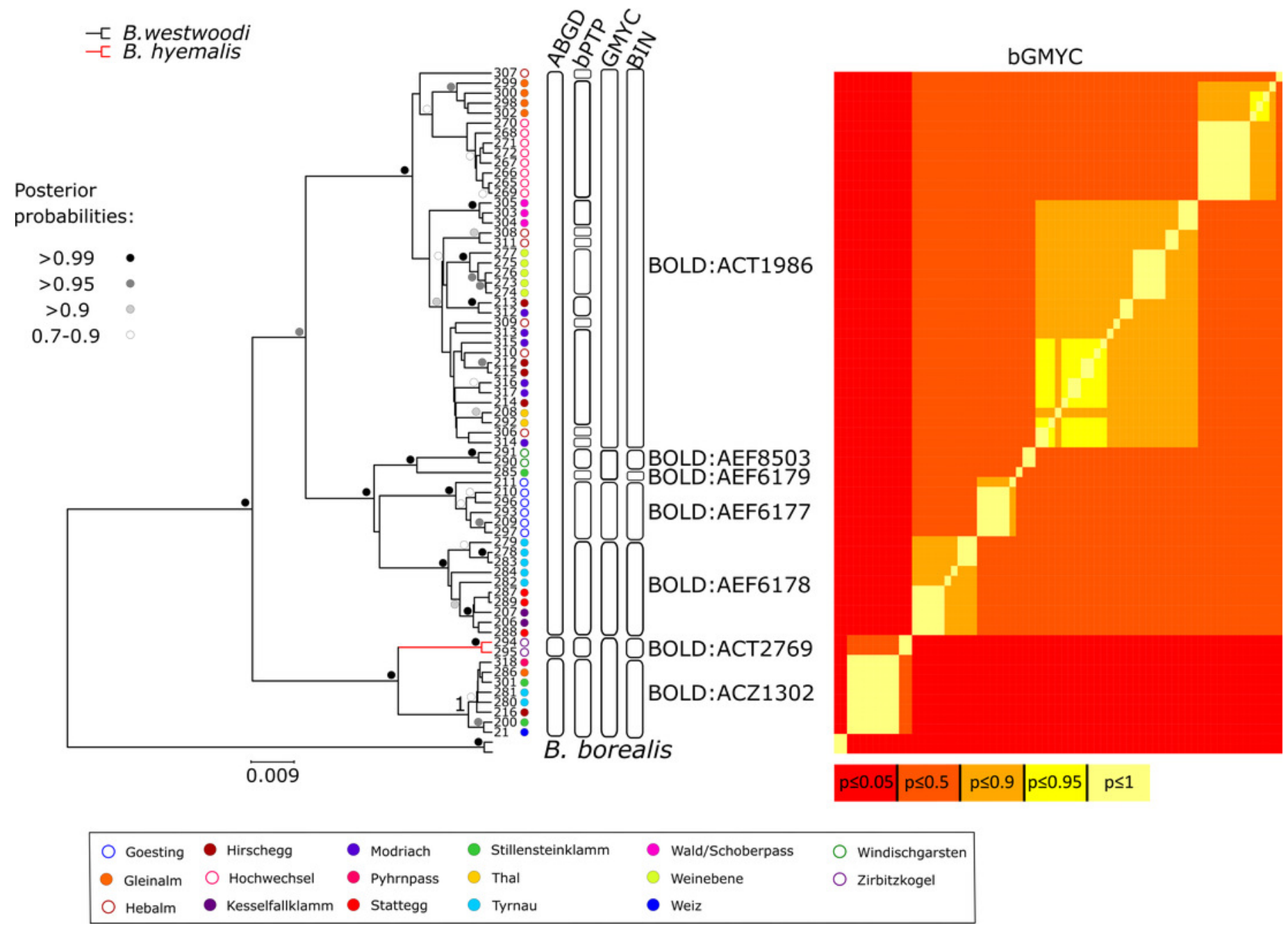




\section{Figure 4}

Map of geographic BIN distribution.

Distribution map of Barcode Index Number (BIN) composition across Austrian sampling localities.

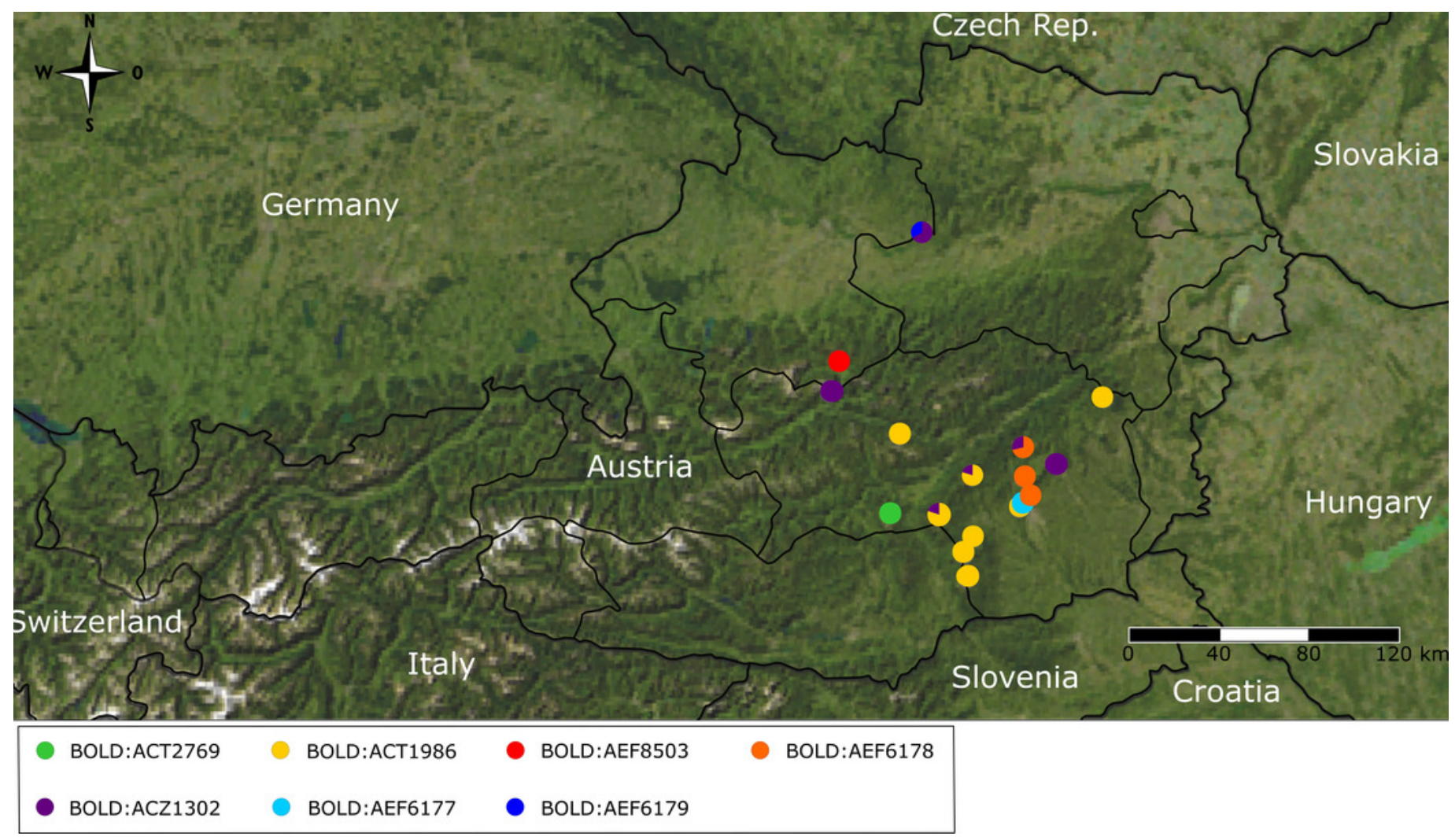




\section{Figure 5}

Sampling map and maximum parsimony network.

Map of Austria and surrounding countries including sampling localities (color coding matches insert in 5b). b) Statistical parsimony network based on $\mathrm{COI}$ sequences. Colors indicate the different sampling localities. Each circle corresponds to one haplotype and its size is proportional to its frequency. Single mutational steps up to five substitutions between haplotypes are indicated by black bars (substitutions $>5$ are represented by numbers next to connective lines). Red frame outlines Boreus hyemalis specimens. 


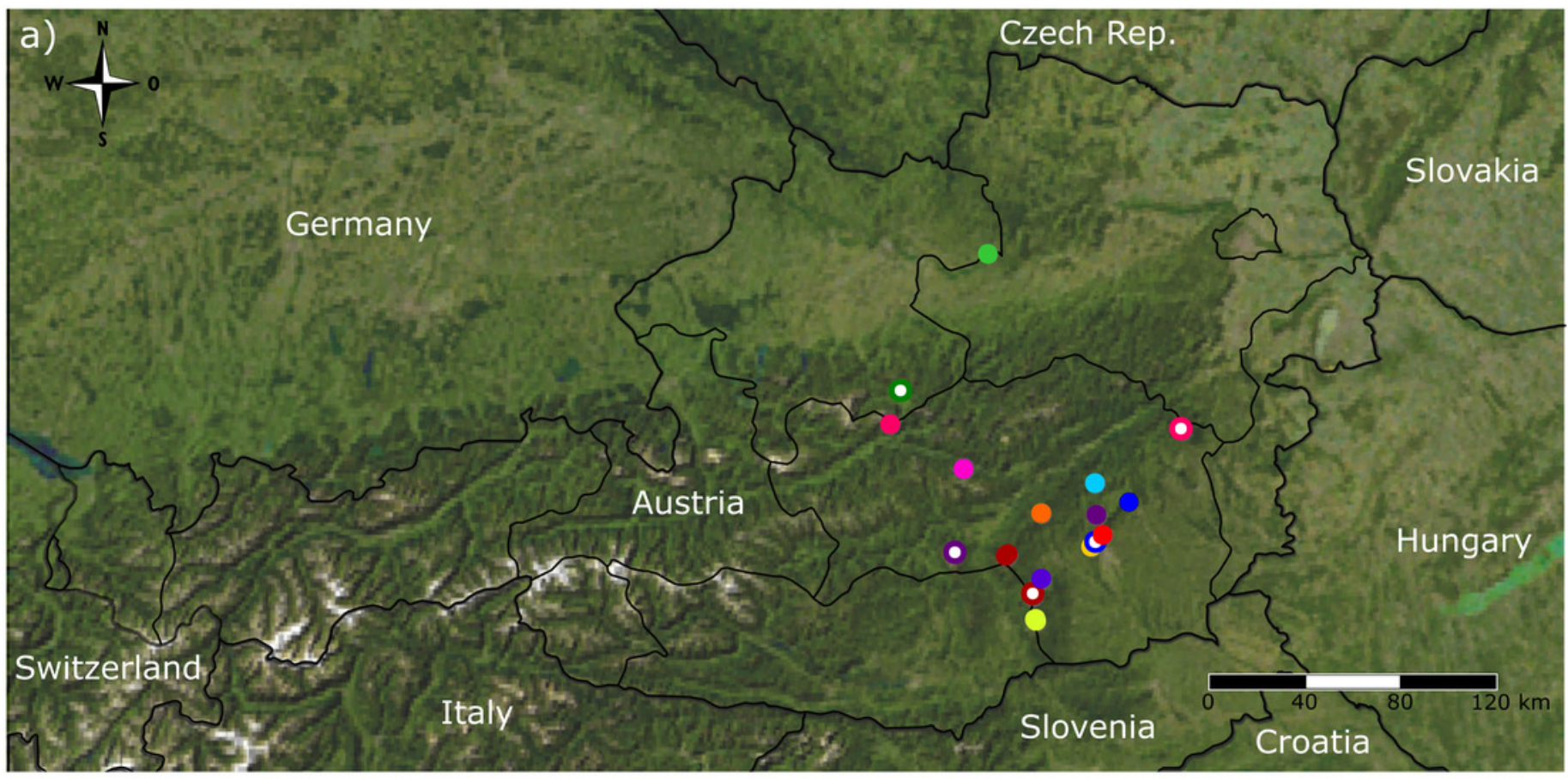

b)

\begin{tabular}{|l|}
\hline Stillensteinklamm \\
Kesselfallklamm \\
Thal \\
Goesting \\
Hirschegg \\
Hochwechsel \\
Weinebene \\
Tyrnau \\
Stattegg \\
Windischgarsten \\
Zirbitzkogel \\
Gleinalm \\
Wald/Schoberpass \\
Hebalm \\
Modriach \\
Pyhrnpass \\
Weiz
\end{tabular}

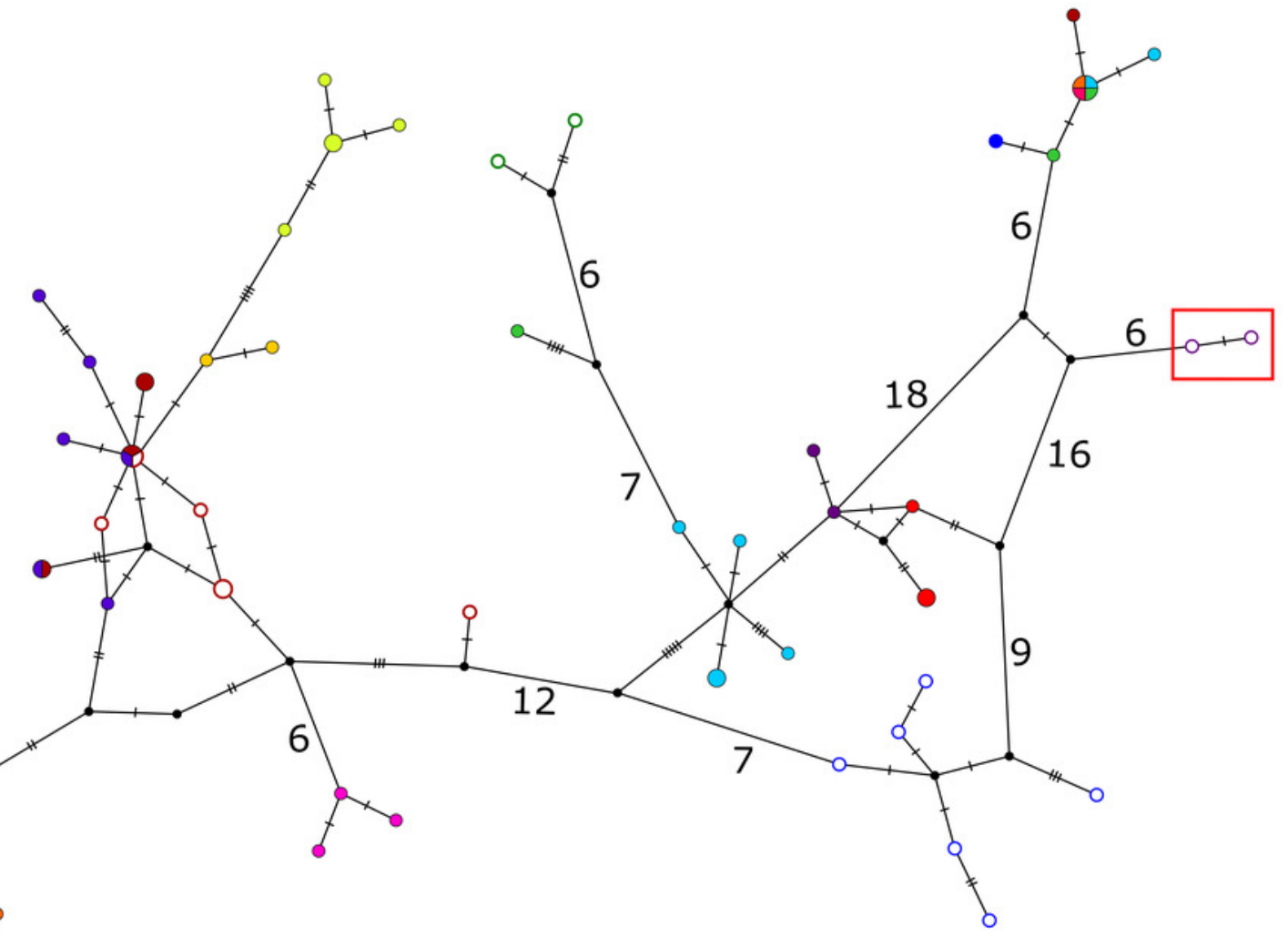

